\title{
Agro-economic performance of crop diversification in rice based cropping systems of northwest Bangladesh
}

\author{
Md. Abu Zaman Sarker ${ }^{1}$, Md. Ashraful Alam ${ }^{1,}$, Akbar Hossain ${ }^{1}$, Md. Abdul Mannaf ${ }^{2}$ \\ ${ }^{1}$ Wheat Research Centre, Bangladesh Agricultural Research Institute, Nashipur, Dinajpur-5200, Bangladesh \\ ${ }^{2}$ Agricultural Research Station, Bangladesh Agricultural Research Institute, Burirhat, Rangpur-5400, Bangladesh
}

\section{Email address:}

zsarker65@gmail.com (M.A.Z. Sarker), ashrafulw@yahoo.com (M.A. Alam), tanjimar2003@yahoo.com (A. Hossain), mannafma@gmail.com (M.A. Mannaf)

\section{To cite this article:}

Md. Abu Zaman Sarker, Md. Ashraful Alam, Akbar Hossain, Md. Abdul Mannaf. Agro-Economic Performance of Crop Diversification in Rice Based Cropping Systems of Northwest Bangladesh. Agriculture, Forestry and Fisheries. Vol. 3, No. 4, 2014, pp. $264-270$. doi: $10.11648 /$ j.aff.20140304.18

\begin{abstract}
Among the winter (Rabi) crops, wheat is one of the most important temperature-sensitive crops and is the second most important grain crop after rice in Bangladesh. An experiment was conducted in research field of Wheat Research Centre, Bangladesh Agricultural Research Institute, Dinajpur, Bangladesh with 5 different cropping patterns including wheat and transplanted (T) Aman rice, and a non-wheat cropping pattern started from Rabi of 2008-09 to Kharif II of 2012 to evaluate the agronomic and economic performance of the patterns in the light soil of northwestern part of Bangladesh. Wheat-Jute-T.Aman Rice cropping pattern gave comparable gross margin with higher benefit-cost ratio (BCR) but need lower total variable cost. Lower gross return and gross margin were obtained from cropping pattern Wheat-T.Aus Rice-T.Aman Rice. Cropping pattern Wheat-Mungbean-T.Aman Rice produced higher gross return and gross margin than the cropping pattern Wheat-T.Aus Rice-T.Aman Rice. Cropping pattern Potato-Wheat-Maize-T.Aman Rice produced higher wheat equivalent yield in all the 4 years. Cropping pattern Wheat-T.Aus Rice-T.Aman Rice produced lower wheat equivalent yield than other cropping patterns and also induced acidity rapidly. Cropping pattern Wheat-Mungbean-T.Aman Rice needed lowest cost but gave economic benefit with comparable BCR.
\end{abstract}

Keywords: Cropping Pattern, Wheat, Rice, Light Soil, Benefit-Cost Ratio (BCR)

\section{Introduction}

The impacts of global warming and climate change are worldwide. For Bangladesh, the impacts are most critical because of its geographical location, high population density, high levels of poverty, and the reliance of many livelihoods on climate-sensitive sectors, such as agriculture [1]. Research projections of global warming for Bangladesh indicate that climate change will severely reduce the growth of various crops such as, wheat, Boro rice, potato and winter vegetables in the north and central parts, due to increasing temperature in winter; lack of rainfall, summer crops by drought in northwestern and by flooding in southeastern parts of the country [2].

Crop diversification is the growing of different species of crops in a farm or area or region or nation either in succession or simultaneously or both together in the course of the year. While crop intensification is the growing of crop with intensive care and management by utilizing modern technique and technology to maximize production in a unit of land with the accommodation of more number of crops per year.

Although Bangladesh is nearly self-sufficient in rice production, other foods such as wheat, vegetables, pulses, oil crops etc. are still deficit to a large extent. Even rice food security has not been achieved at the household level in many poor and extreme poor farm families. Crop diversification increases cropping intensity, raising the productivity of land and labour, generate income and employment which in turn will eliminate food and nutritional insecurity and poverty of farming community in future [3].

In Bangladesh, very large numbers of people depend on intensifying cereal crop production systems for most of their food and a large part of their livelihoods. Traditionally rice has provided almost all of the cereal carbohydrate. During the 1980 s to 2000 s, rice-wheat cropping systems 
became important and wheat chapatti an important part of human diets [4]. Wheat is one of the major cereals in Rabi (winter) season in the northwestern part of Bangladesh. Most of the wheat-growing farmers of the northwestern part of Bangladesh are growing wheat in Wheat-FallowT.Aman Rice cropping pattern in light soil for decades. Some farmers are growing wheat in Wheat-Jute-T.Aman Rice cropping pattern [5]. There is scope of introducing mungbean in fallow period after wheat and some farmers already started growing mungbean in Kharif I after wheat. In some places of northwestern part of Bangladesh, farmers are growing early potato before wheat sowing to earn more from the potato of higher market price. For growing early potato most of the lands remain fallow during Kharif II season due to lack of knowledge or short duration Aman rice varieties [5]. After wheat, farmers are growing maize or mungbean and then transplanted (T) Aman rice [5]. Therefore, there are different cropping patterns which include wheat in Rabi season in this area. One of the major patterns is Potato-Maize-T.Aman Rice in the light soil, which is considered to be more profitable as compared to other existing cropping patterns [5]. A study was, therefore, undertaken in northwestern part of Bangladesh with the objective to evaluate the agro-economic performance of the designed cropping patterns.

\section{Materials and Methods}

A long-term (4 years) experiment was initiated from Rabi season of 2008-09 with different cropping patterns which include wheat and T. Aman rice, and a non-wheat cropping pattern in the research farm of Wheat Research Centre (WRC), Bangladesh Agricultural Research Institute, Dinajpur. The soil texture of the experimental site was sandy loam. Initial soil chemical properties are presented in Table 1 . Soil reaction was moderately acidic, and organic matter and total $\mathrm{N}$ were below the critical level. A list of the patterns with crop and variety, and date of sowing/transplanting and harvesting of different crops is given in Table 2. The plot size for each cropping pattern was $6 \times 4.5 \mathrm{~m}$. Each cropping pattern was replicated thrice. Variety of different crops in the patterns was selected considering its duration, yield performance and other weather adjusting criteria. Recommended fertilizer dose and agronomic practices were followed for each crop.

Table 1. Initial soil chemical properties of the experimental plot of WRC, Dinajpur

\begin{tabular}{|c|c|c|c|c|c|c|}
\hline & pH & $\begin{array}{l}\text { Organic matter } \\
(\%)\end{array}$ & $\begin{array}{l}\text { Total N } \\
(\%)\end{array}$ & $\begin{array}{l}\text { Available P } \\
\text { (ppm) }\end{array}$ & $\begin{array}{l}\text { Exchangeable } K \\
\text { (meq/100g soil) }\end{array}$ & $\begin{array}{l}\text { Available S } \\
\text { (ppm) }\end{array}$ \\
\hline Amount present & 5.65 & 1.08 & 0.051 & 12.34 & 0.09 & 11.56 \\
\hline Critical level & - & 2.00 & 0.100 & 8.00 & 0.08 & 8.00 \\
\hline
\end{tabular}

Table 2. Crop, variety, sowing/transplanting and harvesting date of the cropping patterns

\begin{tabular}{|c|c|c|c|c|}
\hline Cropping Pattern 1 (CP 1): & Potato & \multicolumn{2}{|c|}{ Maize } & T. Aman Rice \\
\hline Variety: & Granola/Diamant/ Cardinal & \multicolumn{2}{|c|}{ Pacific 984} & BRRI dhan31/49 \\
\hline Sowing/transplanting: & $13-23$ Nov. & \multicolumn{2}{|c|}{$06-20 \mathrm{Feb}$} & $27-30$ July \\
\hline Harvesting: & 28 Jan. - 13 Feb. & \multicolumn{2}{|c|}{$09-20$ June } & $10-13$ Nov. \\
\hline Cropping Pattern 2 (CP 2): & Potato & Wheat & Mungbean & T. Aman Rice \\
\hline Variety: & Granola & BARI Gom 24/25 & BARI Mung 6 & Binadhan-7 \\
\hline Sowing/transplanting: & $15-23$ Oct. & $18-23$ Dec. & $04-13$ April & $20-25$ July \\
\hline Harvesting: & 17-23 Dec. & $02-09$ April & $10-30$ June & $11-20$ Oct. \\
\hline Cropping Pattern 3 (CP 3): & Wheat & \multicolumn{2}{|c|}{ Mungbean } & T. Aman Rice \\
\hline Variety: & BARI Gom 24/26 & \multicolumn{2}{|c|}{ BARI Mung 6} & BRRI dhan31/49 \\
\hline Sowing/transplanting: & $20-27$ Nov. & \multicolumn{2}{|c|}{25 March - 02 April } & $27-30$ July \\
\hline Harvesting: & $22-27$ March & \multicolumn{2}{|c|}{10 - 29 June } & $09-13$ Nov. \\
\hline Cropping Pattern 4 (CP 4): & Wheat & \multicolumn{2}{|c|}{ T. Aus Rice } & T. Aman Rice \\
\hline Variety: & BARI Gom 24/26 & \multicolumn{2}{|c|}{ BR 26} & BRRI dhan31/49 \\
\hline Sowing/transplanting: & $20-27$ Nov. & \multicolumn{2}{|c|}{31 March - 05 April } & $27-30$ July \\
\hline Harvesting: & $22-29$ March & \multicolumn{2}{|c|}{$19-21$ June } & $10-12$ Nov. \\
\hline Cropping Pattern 5 (CP 5): & Wheat & \multicolumn{2}{|c|}{ Jute } & T. Aman Rice \\
\hline Variety: & BARI Gom 24/26 & \multicolumn{2}{|c|}{ O 9897} & BRRI dhan31/49 \\
\hline Sowing/transplanting: & $20-27$ Nov. & \multicolumn{2}{|c|}{30 March - 02 April } & $27-30$ July \\
\hline Harvesting: & $22-29$ March & \multicolumn{2}{|c|}{$20-23$ July } & $09-13$ Nov. \\
\hline Cropping Pattern 6 (CP 6): & Potato & Wheat & Maize & T. Aman Rice \\
\hline Variety: & Granola & BARI Gom 24/25 & Pacific 984 & Binadhan-7 \\
\hline Sowing/transplanting: & $15-23$ Oct. & $18-23$ Dec. & 05 - 13 April & $20-26$ July \\
\hline Harvesting: & $17-23$ Dec. & $02-09$ April & $12-15$ July & $11-20$ Oct. \\
\hline
\end{tabular}

Sowing/transplanting and harvesting dates are the ranges of 4 years.

In mungbean, the final harvesting dates are mentioned. 
For early potato, variety Granola was selected for the cropping pattern Potato-Wheat-Mungbean-T.Aman Rice for its rapid growth. Potato was planted in mid-October and it was harvested within 20-23 December. After early potato late wheat was to be sown by 25 December, and for this reason potato was harvested in 60 days. This variety produced a yield, which cannot be possible with other varieties within 60 days. In this pattern wheat variety BARI Gom 24 (2008-09 and 2009-10) and BARI Gom 25 (201011 and 2011-12) were selected for its short duration and heat tolerant capacity [6]. Short duration Binadhan-7 was selected for T. Aman rice so that early potato can be planted timely. Similar varieties of same crops in the cropping pattern Potato-Wheat-Maize-T.Aman Rice were selected for the same reasons. In other cropping patterns rice varieties BRRI dhan31 (2009) and BRRI dhan49 (from 2010 to 2012) was selected. Mungbean variety BARI Mung 6 was selected because of its short duration and can be grown in late condition (after wheat). Hybrid maize variety Pacific 984 was selected because it can be grown with a good yield in Kharif 1 i.e., after potato and wheat. Jute variety O 9897 (Olitorius) was sown just after wheat harvesting and was harvested before T. Aman transplanting.

Table 3. Yield of different crops in different cropping patterns

\begin{tabular}{|c|c|c|c|c|c|c|c|c|c|c|c|c|c|c|c|c|}
\hline \multicolumn{17}{|c|}{ Cropping Pattern 1: } \\
\hline \multirow[t]{2}{*}{ Crops } & \multicolumn{4}{|l|}{ Potato } & \multicolumn{4}{|l|}{ Maize } & \multicolumn{4}{|c|}{ T. Aman Rice } & & & & \\
\hline & 2008-09 & $2009-10$ & 2010-11 & 2011-12 & 2009 & 2010 & 2011 & 2012 & 2009 & 2010 & 2011 & 2012 & & & & \\
\hline Variety & Granola & Granola & Diamant & Cardinal & $\begin{array}{l}\text { Pacific } \\
984\end{array}$ & $\begin{array}{l}\text { Pacific } \\
984\end{array}$ & $\begin{array}{l}\text { Pacific } \\
984\end{array}$ & $\begin{array}{l}\text { Pacific } \\
984\end{array}$ & $\begin{array}{l}\text { BRRI } \\
\text { dhan31 }\end{array}$ & $\begin{array}{l}\text { BRRI } \\
\text { dhan49 }\end{array}$ & $\begin{array}{l}\text { BRRI } \\
\text { dhan49 }\end{array}$ & $\begin{array}{l}\text { BRRI } \\
\text { dhan49 }\end{array}$ & & & & \\
\hline $\begin{array}{l}\text { Yield } \\
\left(\mathrm{kg} \mathrm{ha}^{-1}\right)\end{array}$ & $\begin{array}{l}7,037 \\
( \pm 510)\end{array}$ & $\begin{array}{l}20,494 \\
( \pm 592)\end{array}$ & $\begin{array}{l}36,794 \\
( \pm 962)\end{array}$ & $\begin{array}{l}28,278 \\
( \pm 181)\end{array}$ & $\begin{array}{l}8,155 \\
( \pm 530)\end{array}$ & $\begin{array}{l}8,582 \\
( \pm 234)\end{array}$ & $\begin{array}{l}12,332 \\
( \pm 261)\end{array}$ & $\begin{array}{l}8,776 \\
( \pm 202)\end{array}$ & $\begin{array}{l}2,960 \\
( \pm 145)\end{array}$ & $\begin{array}{l}4,373 \\
( \pm 181)\end{array}$ & $\begin{array}{l}4,741 \\
( \pm 340)\end{array}$ & $\begin{array}{l}4,953 \\
( \pm 223)\end{array}$ & & & & \\
\hline \multicolumn{17}{|c|}{ Cropping Pattern 2: } \\
\hline \multirow[t]{2}{*}{ Crops } & \multicolumn{4}{|l|}{ Potato } & \multicolumn{4}{|l|}{ Wheat } & \multicolumn{4}{|c|}{ Mungbean } & \multicolumn{4}{|c|}{ T. Aman Rice } \\
\hline & 2008 & 2009 & 2010 & 2011 & 2008-09 & $\begin{array}{l}2009- \\
10\end{array}$ & $2010-11$ & 2011-12 & 2009 & 2010 & 2011 & 2012 & 2009 & 2010 & 2011 & 2012 \\
\hline Variety & Granola & Granola & Granola & Granola & $\begin{array}{l}\text { BARI } \\
\text { Gom } 24\end{array}$ & $\begin{array}{l}\text { BARI } \\
\text { Gom } 24\end{array}$ & $\begin{array}{l}\text { BARI } \\
\text { Gom } 25\end{array}$ & $\begin{array}{l}\text { BARI } \\
\text { Gom } 25\end{array}$ & $\begin{array}{l}\text { BARI } \\
\text { Mung } \\
6\end{array}$ & $\begin{array}{l}\text { BARI } \\
\text { Mung } \\
6\end{array}$ & $\begin{array}{l}\text { BARI } \\
\text { Mung } \\
6\end{array}$ & $\begin{array}{l}\text { BARI } \\
\text { Mung } \\
6\end{array}$ & $\begin{array}{l}\text { Bina- } \\
\text { dhan-7 }\end{array}$ & $\begin{array}{l}\text { Bina- } \\
\text { dhan-7 }\end{array}$ & $\begin{array}{l}\text { Bina- } \\
\text { dhan-7 }\end{array}$ & $\begin{array}{l}\text { Bina- } \\
\text { dhan-7 }\end{array}$ \\
\hline $\begin{array}{l}\text { Yield } \\
\left(\mathrm{kg} \mathrm{ha}^{-1}\right)\end{array}$ & $\begin{array}{l}9,660 \\
( \pm 479)\end{array}$ & $\begin{array}{l}7,631 \\
( \pm 208)\end{array}$ & $\begin{array}{l}8,393 \\
( \pm 576)\end{array}$ & $\begin{array}{l}16,652 \\
( \pm 540)\end{array}$ & $\begin{array}{l}3,460 \\
( \pm 49)\end{array}$ & $\begin{array}{l}3,284 \\
( \pm 253)\end{array}$ & $\begin{array}{l}4,591 \\
( \pm 198)\end{array}$ & $\begin{array}{l}3,114 \\
( \pm 63)\end{array}$ & $\begin{array}{l}552 \\
( \pm 97)\end{array}$ & $\begin{array}{l}1,454 \\
( \pm 261)\end{array}$ & $\begin{array}{l}1,323 \\
( \pm 38)\end{array}$ & $\begin{array}{l}1,152 \\
( \pm 119)\end{array}$ & $\begin{array}{l}4,175 \\
( \pm 56)\end{array}$ & $\begin{array}{l}4,362 \\
( \pm 372)\end{array}$ & $\begin{array}{l}5,214 \\
( \pm 209)\end{array}$ & $\begin{array}{l}5,387 \\
( \pm 97)\end{array}$ \\
\hline \multicolumn{17}{|c|}{ Cropping Pattern 3: } \\
\hline \multirow[t]{2}{*}{ Crops } & \multicolumn{4}{|l|}{ Wheat } & \multicolumn{4}{|c|}{ Mungbean } & \multicolumn{4}{|c|}{ T. Aman Rice } & & & & \\
\hline & 2008-09 & $2009-10$ & 2010-11 & 2011-12 & 2009 & 2010 & 2011 & 2012 & 2009 & 2010 & 2011 & 2012 & & & & \\
\hline Variety & $\begin{array}{l}\text { BARI } \\
\text { Gom } 24\end{array}$ & $\begin{array}{l}\text { BARI } \\
\text { Gom } 24\end{array}$ & $\begin{array}{l}\text { BARI } \\
\text { Gom } 26\end{array}$ & $\begin{array}{l}\text { BARI } \\
\text { Gom } 26\end{array}$ & $\begin{array}{l}\text { BARI } \\
\text { Mung } 6\end{array}$ & $\begin{array}{l}\text { BARI } \\
\text { Mung } 6\end{array}$ & $\begin{array}{l}\text { BARI } \\
\text { Mung } 6\end{array}$ & $\begin{array}{l}\text { BARI } \\
\text { Mung } 6\end{array}$ & $\begin{array}{l}\text { BRRI } \\
\text { dhan31 }\end{array}$ & $\begin{array}{l}\text { BRRI } \\
\text { dhan49 }\end{array}$ & $\begin{array}{l}\text { BRRI } \\
\text { dhan49 }\end{array}$ & $\begin{array}{l}\text { BRRI } \\
\text { dhan49 }\end{array}$ & & & & \\
\hline $\begin{array}{l}\text { Yield } \\
\left(\mathrm{kg} \mathrm{ha}^{-1}\right)\end{array}$ & $\begin{array}{l}4,289 \\
( \pm 650)\end{array}$ & $\begin{array}{l}4,649 \\
( \pm 204)\end{array}$ & $\begin{array}{l}4,726 \\
( \pm 237)\end{array}$ & $\begin{array}{l}5,551 \\
( \pm 33)\end{array}$ & $\begin{array}{l}615 \\
( \pm 110)\end{array}$ & $\begin{array}{l}1,506 \\
( \pm 152)\end{array}$ & $\begin{array}{l}1,411 \\
( \pm 147)\end{array}$ & $\begin{array}{l}996 \\
( \pm 23)\end{array}$ & $\begin{array}{l}4,147 \\
( \pm 367)\end{array}$ & $\begin{array}{l}4,571 \\
( \pm 23)\end{array}$ & $\begin{array}{l}5,383 \\
( \pm 290)\end{array}$ & $\begin{array}{l}5,189 \\
( \pm 105)\end{array}$ & & & & \\
\hline \multicolumn{17}{|c|}{ Cropping Pattern 4: } \\
\hline \multirow[t]{2}{*}{ Crops } & \multicolumn{4}{|l|}{ Wheat } & \multicolumn{4}{|c|}{ T. Aus Rice } & \multicolumn{4}{|c|}{ T. Aman Rice } & & & & \\
\hline & 2008-09 & $2009-10$ & 2010-11 & 2011-12 & 2009 & 2010 & 2011 & 2012 & 2009 & 2010 & 2011 & 2012 & & & & \\
\hline Variety & $\begin{array}{l}\text { BARI } \\
\text { Gom } 24\end{array}$ & $\begin{array}{l}\text { BARI } \\
\text { Gom } 24\end{array}$ & $\begin{array}{l}\text { BARI } \\
\text { Gom } 26\end{array}$ & $\begin{array}{l}\text { BARI } \\
\text { Gom } 26\end{array}$ & BR 26 & BR 26 & BR 26 & BR 26 & $\begin{array}{l}\text { BRRI } \\
\text { dhan31 }\end{array}$ & $\begin{array}{l}\text { BRRI } \\
\text { dhan49 }\end{array}$ & $\begin{array}{l}\text { BRRI } \\
\text { dhan49 }\end{array}$ & $\begin{array}{l}\text { BRRI } \\
\text { dhan49 }\end{array}$ & & & & \\
\hline $\begin{array}{l}\text { Yield } \\
\left(\mathrm{kg} \mathrm{ha}^{-1}\right)\end{array}$ & $\begin{array}{l}4,247 \\
( \pm 116)\end{array}$ & $\begin{array}{l}4,780 \\
( \pm 227)\end{array}$ & $\begin{array}{l}4,383 \\
( \pm 45)\end{array}$ & $\begin{array}{l}5,737 \\
( \pm 78)\end{array}$ & $\begin{array}{l}3,149 \\
( \pm 96)\end{array}$ & $\begin{array}{l}3,229 \\
( \pm 26)\end{array}$ & $\begin{array}{l}2,941 \\
( \pm 214)\end{array}$ & $\begin{array}{l}3,041 \\
( \pm 93)\end{array}$ & $\begin{array}{l}3,260 \\
( \pm 133)\end{array}$ & $\begin{array}{l}4,369 \\
( \pm 256)\end{array}$ & $\begin{array}{l}4,793 \\
( \pm 301)\end{array}$ & $\begin{array}{l}4,740 \\
( \pm 115)\end{array}$ & & & & \\
\hline \multicolumn{17}{|c|}{ Cropping Pattern 5: } \\
\hline \multirow[t]{2}{*}{ Crops } & \multicolumn{4}{|l|}{ Wheat } & \multicolumn{4}{|l|}{ Jute } & \multicolumn{4}{|c|}{ T. Aman Rice } & & & & \\
\hline & 2008-09 & $2009-10$ & 2010-11 & 2011-12 & 2009 & 2010 & 2011 & 2012 & 2009 & 2010 & 2011 & 2012 & & & & \\
\hline Variety & $\begin{array}{l}\text { BARI } \\
\text { Gom } 24\end{array}$ & $\begin{array}{l}\text { BARI } \\
\text { Gom } 24\end{array}$ & $\begin{array}{l}\text { BARI } \\
\text { Gom } 26\end{array}$ & $\begin{array}{l}\text { BARI } \\
\text { Gom } 26\end{array}$ & O 9897 & O 9897 & O 9897 & O 9897 & $\begin{array}{l}\text { BRRI } \\
\text { dhan31 }\end{array}$ & $\begin{array}{l}\text { BRRI } \\
\text { dhan49 }\end{array}$ & $\begin{array}{l}\text { BRRI } \\
\text { dhan49 }\end{array}$ & $\begin{array}{l}\text { BRRI } \\
\text { dhan49 }\end{array}$ & & & & \\
\hline $\begin{array}{l}\text { Yield } \\
\left(\mathrm{kg} \mathrm{ha}^{-1}\right)\end{array}$ & $\begin{array}{l}3,986 \\
( \pm 2)\end{array}$ & $\begin{array}{l}4,883 \\
( \pm 400)\end{array}$ & $\begin{array}{l}4,557 \\
( \pm 184)\end{array}$ & $\begin{array}{l}5,318 \\
( \pm 236)\end{array}$ & $\begin{array}{l}2,333 \\
( \pm 33)\end{array}$ & $\begin{array}{l}2,950 \\
( \pm 297)\end{array}$ & $\begin{array}{l}2,892 \\
( \pm 189)\end{array}$ & $\begin{array}{l}3,242 \\
( \pm 128)\end{array}$ & $\begin{array}{l}3,767 \\
( \pm 154)\end{array}$ & $\begin{array}{l}4,341 \\
( \pm 94)\end{array}$ & $\begin{array}{l}4,691 \\
( \pm 312)\end{array}$ & $\begin{array}{l}4,897 \\
( \pm 158)\end{array}$ & & & & \\
\hline Cropping & Pattern 6 & & & & & & & & & & & & & & & \\
\hline Crops & Potato & & & & Wheat & & & & Maize & & & & T. Ama & Rice & & \\
\hline & 2008 & 2009 & 2010 & 2011 & 2008-09 & $\begin{array}{l}2009- \\
10\end{array}$ & $2010-11$ & 2011-12 & 2009 & 2010 & 2011 & 2012 & 2009 & 2010 & 2011 & 2012 \\
\hline Variety & Granola & Granola & Granola & Granola & $\begin{array}{l}\text { BARI } \\
\text { Gom } 24\end{array}$ & $\begin{array}{l}\text { BARI } \\
\text { Gom } 24\end{array}$ & $\begin{array}{l}\text { BARI } \\
\text { Gom } 25\end{array}$ & $\begin{array}{l}\text { BARI } \\
\text { Gom } 25\end{array}$ & $\begin{array}{l}\text { Pacific } \\
984\end{array}$ & $\begin{array}{l}\text { Pacific } \\
984\end{array}$ & $\begin{array}{l}\text { Pacific } \\
984\end{array}$ & $\begin{array}{l}\text { Pacific } \\
984\end{array}$ & $\begin{array}{l}\text { Bina- } \\
\text { dhan-7 }\end{array}$ & $\begin{array}{l}\text { Bina- } \\
\text { dhan-7 }\end{array}$ & $\begin{array}{l}\text { Bina- } \\
\text { dhan-7 }\end{array}$ & $\begin{array}{l}\text { Bina- } \\
\text { dhan-7 }\end{array}$ \\
\hline $\begin{array}{l}\text { Yield } \\
\left(\mathrm{kg} \mathrm{ha}^{-1}\right)\end{array}$ & $\begin{array}{l}10,525 \\
( \pm 638)\end{array}$ & $\begin{array}{l}7,701 \\
( \pm 449)\end{array}$ & $\begin{array}{l}9,494 \\
( \pm 275)\end{array}$ & $\begin{array}{l}17,522 \\
( \pm 852)\end{array}$ & $\begin{array}{l}3,740 \\
( \pm 105)\end{array}$ & $\begin{array}{l}3,685 \\
( \pm 82)\end{array}$ & $\begin{array}{l}4,617 \\
( \pm 210)\end{array}$ & $\begin{array}{l}3,094 \\
( \pm 93)\end{array}$ & $\begin{array}{l}5,813 \\
( \pm 361)\end{array}$ & $\begin{array}{l}9,794 \\
( \pm 166)\end{array}$ & $\begin{array}{l}9,186 \\
( \pm 152)\end{array}$ & $\begin{array}{l}7,303 \\
( \pm 183)\end{array}$ & $\begin{array}{l}3,708 \\
( \pm 376)\end{array}$ & $\begin{array}{l}4,282 \\
( \pm 306)\end{array}$ & $\begin{array}{l}4,382 \\
( \pm 88)\end{array}$ & $\begin{array}{l}5,335 \\
( \pm 194)\end{array}$ \\
\hline
\end{tabular}

Figure in the parentheses indicates the standard error $( \pm \mathrm{SE})$ of the mean.

The spacing of potato was used by BARI technology hand book as $60 \times 25 \mathrm{~cm}$ in 2008-09 and 2009-10, 50×20 and
$50 \times 25 \mathrm{~cm}$ for variety Granola and Diamant, respectively, in 2010-11, and $50 \times 20 \mathrm{~cm}$ for Granola and Cardinal in 2011- 
12 [7]. The spacing of maize was $75 \times 25 \mathrm{~cm}$ in 2009 and 2010 , and $60 \times 25 \mathrm{~cm}$ in 2011 and 2012 in cropping pattern Potato-Maize-T.Aman Rice, and $75 \times 25 \mathrm{~cm}$ in 2009 and $60 \times 25 \mathrm{~cm}$ in 2010,2011 and 2012 in cropping pattern Potato-Wheat-Maize-T.Aman Rice. Wheat seeds were sown in lines 20cm apart continuously@140 kg ha ${ }^{-1}$ for variety BARI Gom 24 and 25 , and $120 \mathrm{~kg} \mathrm{ha}^{-1}$ for variety BARI Gom 26. Mungbean and jute seeds were sown in lines $30 \mathrm{~cm}$ apart continuously @ 25 and $5 \mathrm{~kg} \mathrm{ha}^{-1}$, respectively. Thinning was done at the proper stage of the crops. Twenty to 22 days old seedlings of Aus rice variety BR 26 were transplanted @ 2-3 seedlings per hill. In Aman rice season, 30-32 days old seedlings of BRRI dhan31 (2009) and BRRI dhan49 (2010, 2011 and 2012), and 2125 days old seedlings of Binadhan-7 were used. For early potato less or no fungicide was needed. Liming was done with Dolochun@1,000 kg ha ${ }^{-1}$ in 2011 (during or after $3^{\text {rd }}$ cycle) before T. Aman rice in the cropping patterns PotatoMaize-T.Aman Rice, Potato-Wheat-Mungbean-T.Aman Rice and Potato-Wheat-Maize-T.Aman Rice, and after T. Aman rice in the cropping patterns Wheat-MungbeanT.Aman Rice, Wheat-T.Aus Rice-T.Aman Rice and WheatJute-T.Aman Rice. Potato plots were treated with stable bleaching powder before planting in 2011 (before $4^{\text {th }}$ cycle). Intercultural operations were done properly. Crop was harvested when it was in a state of harvestable maturity. For yield data crops were harvested avoiding border effect. Yields of cereals were adjusted at a moisture level of $12 \%$. Soil samples were collected from $0-15 \mathrm{~cm}$ depth from each plots after 3 and 4 cycles, and analyzed for soil status. Input cost and price of products during the cropping (i.e., current price) and harvesting period were considered for cost and return analysis. For this purpose average cost and returns of 4 years were considered. Benefit-cost ratio was calculated based on total variable cost. Wheat equivalent yield of a cropping pattern was estimated considering only the price of the grain or fibre.

\section{Results and Discussion}

\subsection{Potato}

Early potato produced very low yield in 2 different cropping patterns (CP 2 and 6) in 2008, 2009 and 2010 years because of higher temperature during crop growth and tuberization than normal growing period, and short field duration (Table 3). In 2009, early potato yielded lower than the previous year. In the following year, the yield was satisfactory with closer spacing. In 2011, the yield was very good due to liming before T. Aman rice, soil treatment with stable bleaching powder before planting and use of larger sized tuber as seed.

In 2008-09, potato (var. Granola) in a non-wheat cropping pattern Potato-Maize-T.Aman Rice, which was planted in optimum time and the field duration was 76 days, produced very low yield $\left(7,037 \mathrm{~kg} \mathrm{ha}^{-1}\right)$ due to disease infection (Table $3)$. In 2009-10, yield of potato $\left(20,494 \mathrm{~kg} \mathrm{ha}^{-1}\right)$ was satisfactory. In 2010-11 higher potato yield was obtained from the variety Diamant (36,794 $\left.\mathrm{kg} \mathrm{ha}^{-1}\right)$. In 2011-12, variety Cardinal produced satisfactory yield $\left(28,278 \mathrm{~kg} \mathrm{ha}^{-1}\right)$. Field duration was 82 and 88 days in 2010-11 and 2011-12, respectively, and proper disease control measure was taken.

\subsection{Wheat}

In 2008-09, 2009-10 and 2011-12, grain yields of wheat in 3 cropping patterns (CP 3, 4 and 5), which was sown in optimum time, were higher than the cropping patterns where wheat was sown in late after harvesting potato (Table 3). Grain yields from late sown wheat were also satisfactory. In 2009-10, grain yields of wheat sown in optimum time were higher than that of previous year, but late sown wheat produced lower yield than the previous year. Although 200910 was a good year for wheat but late sown wheat produced low yields compared to optimum sown wheat. This might be due to the leaf rust disease susceptibility of variety BARI Gom 24. In 2010-11, grain yields of wheat were almost similar sown in optimum (BARI Gom 26) and late (BARI Gom 25). In 2011-12, also a very good year for wheat [8], highest grain yield was obtained from the crop sown in optimum time and lowest from the crop sown in late condition (Table 3 ). During $3^{\text {rd }}$ cycle, a little bit lower wheat grain yield and decreasing T. Aus rice yield was observed in cropping pattern Wheat-T.Aus Rice-T.Aman Rice, though latest wheat variety BARI Gom 26 was sown in optimum time. It might be due to the cereal-cereal-cereal pattern and lower $\mathrm{pH}$ among these three patterns. In 2011-12, grain yield of wheat in these patterns (sown in optimum time) were highest ever probably due to the liming and favorable weather condition as well.

\subsection{Mungbean}

Grain yields of mungbean were low in 2009 in two cropping patterns (CP 2 and 3) (Table 3). In the following years, mungbean yields in both the cropping patterns were satisfactory. Proper management and 2-3 times pod-picking resulted in higher yields of mungbean. In 2012, mungbean yield was also satisfactory but lower than the previous year. The late sown mungbean produced lower yield than that sown only 5-7 days earlier except in 2012.

\subsection{Jute, T. Aman Rice and Maize}

Fibre yield of jute was satisfactory in all the 4 years (Table 3). Grain yield of maize in the cropping pattern PotatoMaize-T.Aman Rice was satisfactory in 2009 and 2010. In 2011 and 2012 grain yield of maize was higher than previous years due to closer spacing and proper fertilizer management. In 2012 grain yield of maize was lower than the previous year probably due to a storm during tasseling. Grain yield of the next crop T. Aman rice was not satisfactory in 2009. The variety of $\mathrm{T}$. Aman rice was BRRI dhan31, which had medium field duration (104 days) and is high yielder. After growing potato, in 2009 , maize was grown with an amount of fertilizers which was little bit lesser than the 
recommendation. Although maize yield was not affected greatly, that caused the lower yield of T. Aman rice. Full dose of recommended fertilizers were applied in maize in the following years. In 2010, 2011 and 2012, grain yield of rice was satisfactory with the variety BRRI dhan49. Grain yields of Binadhan-7 (short duration) in 2 cropping patterns (CP 2 and 6) were satisfactory in all the 4 years. The longer duration BRRI dhan31 failed to produce satisfactory yield even in a pattern where the previous crop was jute (CP 5) or mungbean (CP 3). It was observed that this crop was infested severely by leafhoppers after heading in 2009 . In the mean time Binadhan-7 was already harvested. In late sown maize i.e., in cropping pattern Potato-Wheat-Maize-T.Aman Rice, grain yield was satisfactory in 2009, but higher yield was obtained in the following years due to closer spacing and proper management.

\subsection{Impacts of Different Cropping Patterns}

The highest wheat equivalent yield was obtained from one of the cropping patterns in 2009-10, which includes early potato and maize (CP 6) (Table 4). This pattern produced higher wheat equivalent yield in all the 4 years and thus higher equivalent yield on average of the years. PotatoWheat-Mungbean-T.Aman Rice (CP 2) cropping pattern also produced comparable wheat equivalent yield in all the 4 years. On an average this patterns produced similar wheat equivalent yield with the cropping pattern Potato-MaizeT.Aman Rice (CP 1). The all cereals cropping pattern Wheat-T. Aus Rice- T. Aman Rice (CP 4) produced the lowest wheat equivalent yield in all the 4 years. The small variation in the wheat equivalent yield might be due to yield of crop and farm gate price of the product especially rice.
Table 4. Wheat equivalent yields of different cropping patterns

\begin{tabular}{|c|c|c|c|c|c|}
\hline \multirow{2}{*}{$\begin{array}{l}\text { Cropping } \\
\text { pattern }\end{array}$} & \multicolumn{4}{|c|}{ Wheat equivalent yield $\left(\mathrm{kg} \mathrm{ha}^{-1}\right)$} & \multirow{2}{*}{$\begin{array}{l}\text { Mean } \\
\text { (cropping } \\
\text { pattern) }\end{array}$} \\
\hline & 2008-09 & 2009-10 & 2010-11 & 2011-12 & \\
\hline CP 1 & 17,395 & 21,847 & 23,011 & 17,340 & 19,898 \\
\hline CP 2 & 19,284 & 21,663 & 19,518 & 17,828 & 19,573 \\
\hline CP 3 & 10,729 & 14,840 & 14,367 & 12,550 & 13,121 \\
\hline $\mathrm{CP} 4$ & 10,400 & 12,815 & 11,225 & 11,074 & 11,378 \\
\hline CP 5 & 12,270 & 15,979 & 13,320 & 13,731 & 13,825 \\
\hline $\mathrm{CP} 6$ & 21,654 & 24,489 & 23,018 & 19,483 & 22,161 \\
\hline Mean (year) & 15,288 & 18,606 & 17,410 & 15,334 & \\
\hline $\begin{array}{l}\mathrm{LSD}_{0.05}=8 \\
\mathrm{CV}(\%)=6 .\end{array}$ & (year), & $\begin{array}{l}\text { (CP) a } \\
5.24(C\end{array}$ & $441(\mathrm{yc}$ & CP); & \\
\hline
\end{tabular}

For details of the cropping patterns, see Table 2 and 3.

During the $3^{\text {rd }}$ crop cycle, in the cropping pattern where $\mathrm{T}$. Aus rice was included (CP 4), it was observed that growth of wheat was not satisfactory. The soil reaction was examined in the cropping patterns where wheat was sown in optimum time. It was found that soil $\mathrm{pH}$ of the plots was lower than the initial stage and became strongly acidic (Table 1 and 5). Among these three cropping patterns lowest $\mathrm{pH}$ was observed in the cropping pattern (CP 4) where T. Aus rice was included and for this reason growth of wheat in this pattern was slow. It was decided to apply lime into these plots before wheat of the $4^{\text {th }}$ cycle to get the maximum benefit of liming. Liming was done accordingly and $\mathrm{pH}$ was increased due to liming, and higher grain yield of wheat was obtained from these patterns in 2011-12 (Table 3). In other cropping patterns $\mathrm{pH}$ was examined later and found that soil reaction was moderately acidic. The observed $\mathrm{pH}$ might be higher than the actual in rabi season, since it was tested in wet season. We decided to apply lime also into these plots before T. Aman rice because there was no time window before potato i.e., in Rabi season in these cropping patterns. Liming was done accordingly.

Table 5. Soil reaction and nutrient status of plots for different cropping patterns

\begin{tabular}{|c|c|c|c|c|c|c|c|c|c|c|c|c|c|c|}
\hline \multirow{2}{*}{$\begin{array}{l}\text { Crop- } \\
\text { ping } \\
\text { pattern }\end{array}$} & \multirow{2}{*}{$\begin{array}{l}\text { pH } \\
20 \text { Dec. } \\
2010\end{array}$} & \multirow[b]{2}{*}{$\begin{array}{l}\text { 04July } \\
2011\end{array}$} & \multirow[b]{2}{*}{$\begin{array}{l}\text { After } 3 \\
\text { cycles }\end{array}$} & \multirow[b]{2}{*}{$\begin{array}{l}\text { After } 4 \\
\text { cycles }\end{array}$} & \multicolumn{2}{|c|}{$\begin{array}{l}\text { Organic matter } \\
(\%)\end{array}$} & \multicolumn{2}{|l|}{$\begin{array}{l}\text { Total N } \\
(\%)\end{array}$} & \multicolumn{2}{|c|}{$\begin{array}{l}\text { Available P } \\
(\mu \mathrm{g} / \mathrm{g} \text { soil })\end{array}$} & \multicolumn{2}{|c|}{$\begin{array}{l}\text { Exchangeable K } \\
\text { (meq/100g soil) }\end{array}$} & \multicolumn{2}{|l|}{$\begin{array}{l}\text { Available } S \\
(\mu \mathrm{g} / \mathrm{g} \text { soil })\end{array}$} \\
\hline & & & & & $\begin{array}{l}\text { After } 3 \\
\text { cycles }\end{array}$ & $\begin{array}{l}\text { After } 4 \\
\text { cycles }\end{array}$ & $\begin{array}{l}\text { After } 3 \\
\text { cycles }\end{array}$ & $\begin{array}{l}\text { After } 4 \\
\text { cycles }\end{array}$ & $\begin{array}{l}\text { After } 3 \\
\text { cycles }\end{array}$ & $\begin{array}{l}\text { After } 4 \\
\text { cycles }\end{array}$ & $\begin{array}{l}\text { After } 3 \\
\text { cycles }\end{array}$ & $\begin{array}{l}\text { After } 4 \\
\text { cycles }\end{array}$ & $\begin{array}{l}\text { After } 3 \\
\text { cycles }\end{array}$ & $\begin{array}{l}\text { After } 4 \\
\text { cycles }\end{array}$ \\
\hline CP 1 & - & 5.98 & 6.14 & 6.40 & 1.14 & 1.72 & 0.057 & 0.085 & 13.19 & 17.68 & 0.15 & 0.14 & 75.38 & 9.39 \\
\hline $\mathrm{CP} 2$ & - & 6.01 & 6.01 & 6.50 & 1.12 & 1.86 & 0.053 & 0.093 & 15.28 & 15.61 & 0.14 & 0.15 & 91.57 & 11.17 \\
\hline $\mathrm{CP} 3$ & 4.97 & - & 5.72 & 6.50 & 1.14 & 1.79 & 0.057 & 0.089 & 11.80 & 10.52 & 0.10 & 0.13 & 70.70 & 7.98 \\
\hline $\mathrm{CP} 4$ & 4.80 & - & 5.73 & 6.30 & 1.28 & 1.40 & 0.060 & 0.069 & 11.97 & 10.00 & 0.10 & 0.13 & 78.37 & 7.81 \\
\hline CP 5 & 5.10 & - & 5.87 & 6.33 & 1.19 & 1.70 & 0.057 & 0.084 & 9.91 & 9.87 & 0.12 & 0.13 & 86.30 & 9.91 \\
\hline CP 6 & - & 5.59 & 6.19 & 6.47 & 1.37 & 1.58 & 0.063 & 0.079 & 23.08 & 21.65 & 0.26 & 0.20 & 122.58 & 12.86 \\
\hline
\end{tabular}

For details of the cropping patterns, see Table 2 and 3.

Each value is a mean of 3 replications.

Although the potato tuber yield in the cropping pattern Potato-Maize-T.Aman Rice in 2008-09 was lower than the next year and the national average; total return of potato was not too low because of higher price. In 2010-11, potato tuber yield was higher than previous years but the price was very low, and for this reason and higher input cost, especially seed cost, gross margin was very low. In 2011-12, gross margin was higher than the previous year due to lower seed cost. In 2011, gross return and gross margin of next crop maize was very high due to its higher yield and higher price. In 2012, price of grain was higher, but the input cost, especially for labour and seed, was also higher. For this reason and a little bit lower yield than 2011 the gross margin was less. In 2009, potato tuber yield was lower in early sowing but the gross margin was about Tk 70,000 within 60 days because of high market price. The price of the potato tuber in the previous year was lower than the usual. Gross margin was also low in 2010-11 even 
in early sown potato because of low farm gate price. Farm gate price of the rice was higher in the $2^{\text {nd }}$ and $3^{\text {rd }}$ year than the previous year except Binadhan-7. In 2011 ( $3^{\text {rd }}$ year), though it was harvested one month earlier price of grain of Binadhan-7 was lower than BRRI dhan49. On an average of the 4 years, higher gross return was found in 3 cropping patterns (CP 1, 2 and 6) where potato was included (Fig. 1).
Among these, one cropping pattern which included wheat (CP 6) produced highest gross return and gross margin. Maize was involved in 2 among these 3 cropping patterns. Out of these 3 cropping patterns 2 (CP 2 and 6) were consisting of 4 crops. In these cropping patterns higher cost was also involved.

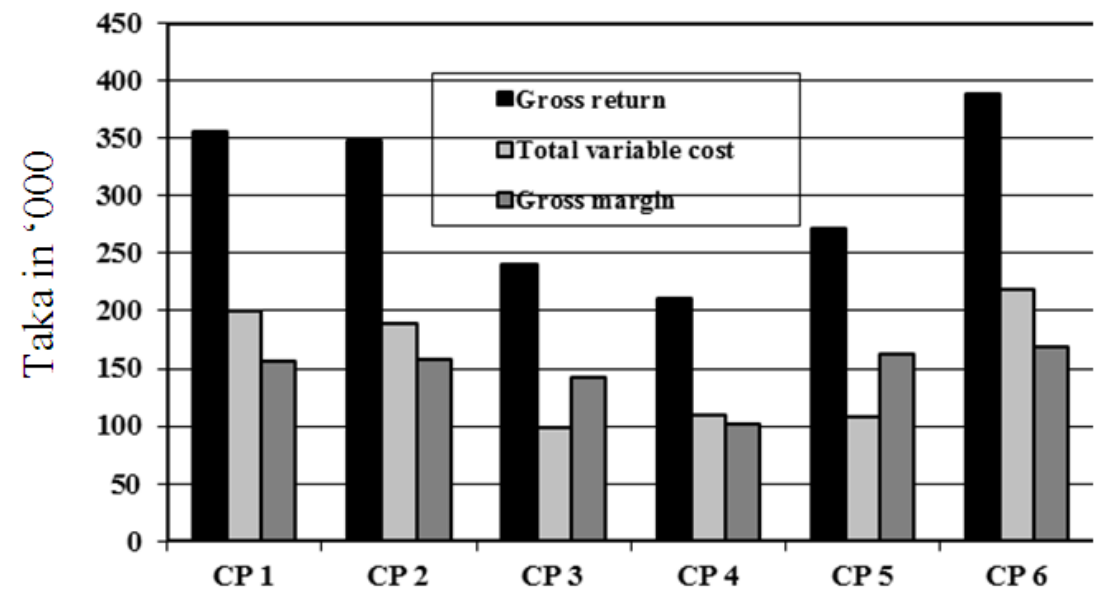

Fig. 1. Gross return, gross margin and total variable cost of 6 cropping patterns tested in light soil (Four years'average). For details of the patterns see the Materials and Methods.

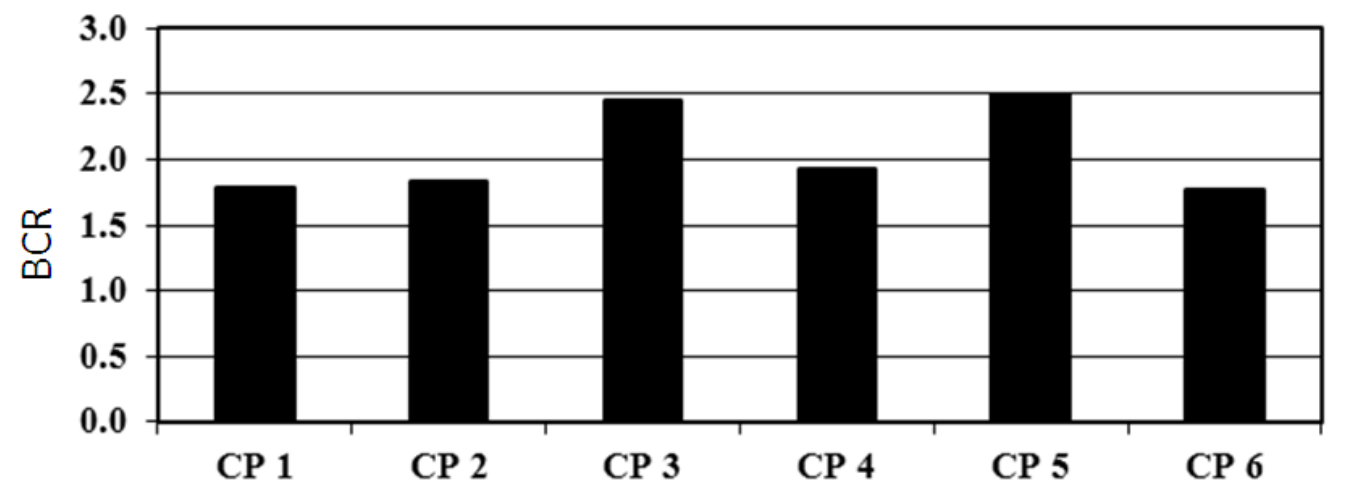

Fig. 2. Benefit-cost ratio (BCR) of 6 cropping patterns. For details of the patterns see the Materials and Methods. BCR was calculated based on total variable cost

Although early-planted potato produced lower yield than the optimum planted potato, higher gross margin and gross return were obtained from these patterns. The early plantation of potato can accommodate 4 crops including wheat. Lower gross return and gross margin were obtained from all cereals based cropping patterns in which T. Aus rice (CP 4) was included. This might be due to the lower yield of T. Aus rice and its lower market price. WheatMungbean-T.Aman Rice (CP 3) cropping pattern produced higher gross return and gross margin than Wheat-T.Aus Rice-T.Aman Rice cropping pattern. These cropping patterns also needed the minimum cost. Gross return and gross margin were highest in cropping pattern Wheat-JuteT.Aman Rice (CP 5) among 3-crops cropping patterns which included wheat. This cropping pattern produced higher gross margin than cropping pattern Potato-MaizeT.Aman Rice. Almost similar gross margin was obtained from the cropping pattern Potato-Wheat-Mungbean-
T.Aman Rice (CP 2). The market price of jute fibre and sticks was satisfactory. The higher benefit-cost ratio (BCR) was found in the cropping pattern Wheat-Jute-T.Aman Rice and Wheat-Mungbean-T.Aman Rice (Fig. 2).

\subsection{Soil Fertility Amendment}

In all the cropping patterns soil organic matter, available $\mathrm{P}$, exchangeable $\mathrm{K}$ and available $\mathrm{S}$ increased after 3 cycles (Table 5). Total $\mathrm{N}$ also increased to some extent. After 4 cycles all the parameters increased farther with some exceptions. Substantial amount of well decomposed cowdung was applied before every upland crop except mungbean in all the patterns. Residues of some crops such as mungbean, maize etc. were also incorporated. For these reasons soil organic matter and nutrients increased. Therefore, soil fertility can be maintained by proper fertilizer management in intensive crop cultivation. 
Furthermore, adequate intercultural operations, soil amendment and soil treatment along with proper fertilizer management produced higher crop yield.

From the above results, it can be suggested that 3 cropping patterns, which include potato, are suitable for rich farmers. Two of the 3-crops cropping patterns which included wheat viz., Wheat-Mungbean-T.Aman Rice and Wheat-Jute-T.Aman Rice can be suggested for the marginal farmers for its low cost involvement and higher BCR. The cropping pattern Wheat-T.Aus Rice-T.Aman Rice cannot be suggested for its lower wheat equivalent yield, lower gross return and gross margin than other cropping patterns, and it includes all cereals and induced acidity faster. Growing of 4 crops in a year in a land (CP 2 and 6) and including a crop (mungbean) into the fallow period in a cropping pattern (CP 2 and 3) could increase the cropping intensity.

\section{Conclusion}

Early planted potato produced lower yield but it can accommodate a total of 4 crops in a cropping pattern with higher gross return and gross margin. Total variable cost, gross return and gross margin were higher in a cropping pattern where potato was included. Wheat-Jute-T.Aman Rice cropping pattern also gave higher gross margin with higher BCR than cropping patern Potato-Maize-T. Aman Rice, but need lower total variable cost. Wheat-T.Aus RiceT.Aman Rice cropping pattern produced lower wheat equivalent yield, gross return and gross margin than the other patterns. Cropping pattern Wheat-Mungbean-T.Aman Rice produced higher gross return and gross margin than the cropping pattern Wheat-T.Aus Rice-T.Aman Rice. Cropping pattern Wheat-Mungbean-T.Aman Rice needed lowest cost but gave economic benefit with comparable BCR.

Therefore, two 4-crops cropping patterns viz., PotatoWheat-Maize-T.aman Rice and Potato-Wheat-Mungbean-
T.aman Rice with a 3-crops cropping patterns (PotatoMaize-T.Aman Rice) are suitable for the light soil of northwestern part of Bangladesh. Additionally other two 3crops cropping patterns viz., Wheat-Jute-T.Aman Rice and Wheat-Mungbean-T.Aman Rice can be recommended for the region, especially for the marginal farmers.

\section{References}

[1] Climate Change Cell, "Adaptive Crop Agriculture Including Innovative Farming Practices in Haor Basin. Climate Change Cell", DoE, MoEF; Component 4b, CDMP, MoFDM, Dhaka, 2009

[2] A. Hossain, and J.A. Teixeira da Silva,. Phenology, "Growth and Yield of Three Wheat (Triticum aestivum L.) Varieties as Affected by High Temperature Stress". Not. Sci.Biol., 4(3): 97-109, 2013

[3] J. Shopan, M.S.U. Bhuiya, M.A. Kader, and M.K. Hasan, "The feasibility of crop diversification in rice based cropping systems in haor ecosystem". J. Bangladesh Agril. Univ., 10(2): 211-216, 2012

[4] M.Y. Ali, S.R. Waddington, D. Hodson, J. Timsina, and J Dixon, "Maize-rice cropping systems in Bangladesh: Status and research opportunities". Journal of Agricultural Science and Technology, 3(6): 35-53,2009

[5] M.J. Kabir, and M. Islam, "Study on agronomically and economically dominant cropping patterns in some selected areas of Barisal district". Bangladesh J. Agril. Res., 37(1): 55-65, 2012.

[6] BARI (Bangladesh Agricultural Research Institute), 2012. Handbook on Agro-technology.

[7] M.A.M. Miah, T.M.B. Hossain, S. Hossain, M.S. Kadian, and M. Hossain, "Farmers' perception about variety development and abiotic stresses on potato cultivation in Bangladesh”. Bangladesh J. Agril. Res., 38(3): 401-416, 2013

[8] BBS (Bangladesh Bureau of Statistics), 2013. Statistical Yearbook of Bangladesh 